\title{
Integrasi metode balanced scorecard dan analytical hierarchy process (AHP) untuk mengukur kinerja fakultas teknik universitas krisnadwipayana
}

\author{
Ismail Kurnia $^{1)}$, Mutoharoh ${ }^{2)}$, Prima Fithri ${ }^{3)}$ \\ ${ }^{12}$ Program Studi Teknik Industri, Fakultas Teknik, Universitas Krisnadwipayana \\ ${ }^{3}$ Jurusan Teknik Industri, Fakultas Teknik, Universitas Andalas \\ ismailkurnia@yahoo.com*
}

\begin{abstract}
ABSTRAK
Semakin banyaknya jumlah Perguruan Tinggi Swasta (PTS) di Indonesia dari tahun ke tahun menuntut PTS bersaing untuk memiliki sebuah kinerja dan kualitas kerja yang baik agar Perguruan Tinggi Swasta tersebut dapat bertahan dan selalu memiliki mahasiswa. Tidak terkecuali untuk Universitas Krisnadwipayana (UNKRIS) juga bersaing dengan PTS lainnya yang ada di Jakarta untuk tetap bertahan dan memiliki kualitas yang baik. Untuk itu Unkris diharuskan dapat beradaptasi, berkembang dan melakukan perbaikan melalui pembelajaran organisasi. Sehingga Unkris perlu merancang strategi peningkatan kinerja yang dapat dilakukan dengan menggunakan metode Anaytic Hierarchy Process (AHP) dan Balance Scored Card (BSC). Berdasarkan hasil kuesioner, didapatkan 23 sasaran strategis, yang kemudian dirumuskan indikator kinerja (KPI) dari masingmasing sasaran strategis tersebut. Berdasarkan hasil perhitungan metode Analytical Hirarchy Process (AHP) sasaran strategis yang menjadi prioritas dengan bobot paling besar, yaitu meningkatkan penerimaan fakultas dengan bobot akhir $10 \%$. Prioritas berikutnya adalah meningkatkan jumlah dosen berpendidikan S2 dan S3 dengan jumlah bobot akhir 9\%, meningkatkan alokasi dana operasional yang ditujukan untuk kegiatan Tridarma dengan bobot $8 \%$, kemudian untuk meningkatkan jumlah penerimaan mahasiswa dengan bobot $7 \%$, lalu meningkatkan realisasi anggaran, dan meningkatkan IPK lulusan serta meningkatkan dukungan teknologi informasi dalam PBM dengan bobot yang didapatkan masing-masing 6\%. Penetapan target dan inisiatif stretegis menjadi langkah berikutnya, dimana target setiap sasaran strategis dirumuskan untuk 3 tahun mendatang berdasarkan kondisi pada saat sekarang.
\end{abstract}

Kata kunci: Kinerja Perguruan Tinggi, FT-Universitas Krisnadwipayana, Analytical Hierarchy Process (AHP) \& Balance Scorecard (BSC).

\section{ABSTRACT}

The number of private universities (PTS) in Indonesia is increasing from year to year. This requires PTS to compete to have good performance and quality so that the PTS can survive and always have students. Krisnadwipayana University (UNKRIS) also competes with other private universities in Jakarta to stay afloat and have good quality. For this reason, private universities are required to always be able to adapt, develop and make improvements through organizational learning. This makes the idea to continue research to design a strategy to improve the performance of Krisnadwipayana University using the Anaytic Hierarchy Process (AHP) and Balanced Scored Card (BSC) methods. Based on the results of the questionnaire, 23 strategic targets were obtained, which were then formulated in terms of performance indicators (KPI) for each of these strategic targets. Based on the Analytical Hierarchy Process (AHP) method, strategic targets were obtained which became the priority with the greatest weight, namely increasing faculty acceptance with a final weight of $10 \%$. The next priority is to increase the number of lecturers with S2 and S3 education with a final weight of $9 \%$, increase the allocation of operational funds for Tridarma activities with a weight of 8\%, increase the number of student admissions with a weight of 7\%, and increase budget realization, increase the GPA of graduates and increase technology support. information in the PBM with a weight of 6\% each. Setting targets and strategic initiatives is the next step, where the targets of each strategic target are formulated for the next 3 years based on current conditions.

Keywords: Higher Education Performance, FT-Krisnadwipayana University, Analytical Hierarchy Process (AHP) \& Balanced scorecard (BSC). 
diunggah: Oktober 2021, direvisi: November 2021, diterima: Desember 2021, dipublikasi: Desember 2021

Copyright (c) 2021 Ismail Kurnia, Mutoharoh, Prima Fithri

This is an open access article under the CC-BY license

\section{PENDAHULUAN}

Semakin banyaknya jumlah Perguruan Tinggi Swasta (PTS) di Indonesia dari tahun ke tahun menuntut PTS bersaing untuk mempunyai kinerja dan kualitas kerja yang baik agar PTS tersebut dapat bertahan dan selalu memiliki mahasiswa. Tidak terkecuali untuk Universitas Krisnadwipayana (UNKRIS) juga bersaing dengan PTS lainnya yang ada di Jakarta untuk tetap bertahan dan memiliki kualitas yang baik. Berdasarkan hasil penelitian terdahulu tentang analisa kualitas pelayanan Fakultas Teknik UNKRIS, bahwa harapan dan yang dirasakan oleh mahasiswa memiliki gap yang negatif yang artinya tidak ada yang dirasakan oleh mahasiswa terhadap pelayanan yang diberikan sesuai dengan harapan mahasiswa. Unkris perlu menerapkan beberapa pemikiran baru yang memiliki unsur fleksibilitas, kecepatan, inovasi, dan integrasi.

Unsur-unsur seperti : fleksibilitas, kecepatan, inovasi dan integrasi membutuhkan sumber daya manusia yang memiliki kreativitas penuh. Kreativitas tersebut bisa muncul dari sumber daya manusia yang memiliki keunggulan dalam ilmu pengetahuan. Dengan demikian, PTS termasuk Unkris diharapkan tidak hanya mampu menghasilkan lulusan terbaik, tetapi juga mampu mengembangkan dua hal yang terkandung dalam Tri Dharma perguruan tinggi, yaitu meneliti dengan hasil riset yang berkualitas tinggi dan mengembangkan teknologi guna pengabdian kepada masyarakat. Untuk itu Unkris diharuskan selalu mampu beradaptasi, berkembang dan melakukan perbaikan melalui pembelajaran organisasi. Hal ini menjadikan ide untuk melanjutkan penelitian untuk merancang strategi peningkatan kinerja Universitas Krisnadwipayana dengan menggunakan metode Anaytic Hierarchy Process (AHP) dan Balance Scored Card (BSC). Rancangan strategi ini akan sangat berguna untuk UNKRIS sebagai pedoman menerapkan apa saja yang akan dilakukan untuk meningkatkan kinerja perguruan tinggi tidak hanya dari segi kualitas pelayanan di UNKRIS.

Metode Analytical Hierarchy Process (AHP) merupakan suatu alat analisa yang digunakan dalam hal membuat keputusan pada kondisi dengan faktor-faktor kompleks, terutama pada keputusan yang bersifat subjektif. Kriteria dan subkriteria ini menjadi acuan bagi manajemen PTS sebagai strategi untuk meningkatkan kinerja PTS di Jakarta. Ini pada dasarnya merupakan model kenyataan dimana setiap dari keputusan melibatkan lebih dari satu variabel tunggal.

Penelitian ini penting untuk dilakukan karena dapat menentukan model terbaik dalam strategi Peningkatan Kinerja Perguruan Tinggi Swasta.

Hasil dari penelitian ini memberikan kontribusi bagi setiap pengambil keputusan atau manajemen PTS sebagai bahan acuan dalam hal member kebijakan untuk meningkatkan Kinerja.

\section{METODE}

Metode penelitian yang digunakan pada penelitian ini adalah metode survei. Tahap pertama yang harus dilakukan dalam penelitian ini adalah melakukan rapat internal dengan dosen, mahasiswa dan seluruh stakeholder serta mencari atribut-atribut yang diinginkan oleh para stakeholder terhadap pelayanan kinerja manajemen yang diberikan oleh FT UNKRIS. Metode yang dilakukan untuk mendapatkan informasi tersebut adalah dengan menggunakan metode wawancara, kuesioner dan observasi untuk mendapatkan data tingkat kinerja saat ini FT UNKRIS. 
Setelah didapatkannya informasi yang diinginkan, selanjutnya dilakukan perancangan perancangan sistem pengukuran kinerja perusahaan dengan menggunakan metode Balanced scorecard. Adapun tahapan-tahapannya meliputi:

1. Menentukan Ukuran Arsitektur

Penentuan arsitektur dilakukan melalui dua tahap, yaitu tahap awal didasarkan pada pemilihan unit bisnis yang memeiliki kontrol langsung dengan bidang keuangan, pelanggan, proses bisnis internal, serta pembelajaran dan pertumbuhan. Sedangkan pada tahap kedua yaitu unit bisnis yang diidentifikasi berdasarkan karakteristiknya, proses yang terjadi pada stakeholders nya, dan sistem pengukuran kinerja.

2. Menentukan Tujuan Strategis

Tujuan strategis merupakan tahapan yang digunaka dalam melakukan perancangan sistem pengukuran kinerja. Hal ini dapat diperoleh berdasarkan hasil wawancara dan diskusi dengan manajemen perusahaan, tentang maksud yang terkandung didalam visi, misi dan strategi perusahaan.

Setiap atribut ukuran kinerja harus menunjukan pola keterkaitan antar ukuran kinerja dan mampu mewakili keempat perspektif dalam BSC (Kaplan, dkk, 2000). Kemudian atribut ukuran kinerja yang didapatkan dari hasil diskusi tersebut diintegrasikan dengan menggunakan metode AHP.

3. Memilih dan Merancang Ukuran

Pada tahapan ini, penentuan sasaran strategik perlu ditetapkan Key Performance Indicator (KPI) berdasarkan tujuan awal strategis FT-UNKRIS. Penentuan maupun penetapan ukuran kinerja merupakan bagian yang krusial dalam merancang sistem pengukuran kinerja. Sehingga dalam penentuannya harus berdasarkan penjabaran dari visi dan misi perusahaan.

4. Menentukan Target

Penetapan target kinerja yang akan dicapai didasarkan tujuan perusahaan, kinerja masa lalu dan potensi perusahaan. Target yang digunakan merupakan target absolut sebagai acuan ideal dan target realistik untuk memantau pencapaian prestasiprestasi perusahaan.

Setelah faktor-faktor tersebut terpenuhi, maka langkah selanjutnya adalah pengolahan data menggunakan metode AHP. Metode ini digunakan untuk memberi bobot prioritas dari berbagai faktor yang telah terpenuhi, lalu dari faktor-faktor tersebut faktor mana yang mempunyai bobot terbesar.

\section{HASIL DAN PEMBAHASAN}

\section{Perancangan sistem pengukuran kinerja}

Sistem pengukuran kinerja menggunakan metode Balanced Score Card (BSC) terbagi atas penentukan ukuran kinerja, pembobotan dan menentukan target serta inisiatif strategis.

\section{a. Penentuan Ukuran Kinerja}

Pada penentuan ukuran kinerja terbagi menjadi ukuran hasil (lag indicator) dan ukuran pemacu kinerja (lead indicator) dari masing-masing sasaran strategis. Ukuran kinerja nantinya diperlukan untuk mengukur pencapaian sasaran strategis.

b. Pembobotan

Pembobotan tiap perspektif dan ukuran hasil menggunakan metode Analytical Hirarchy Process atau AHP dari Saaty. Perbandingan untuk masing-masing tingkat kepentingan antar kriteria dengan kriteria yang lainnya dalam metode AHP akan dilakukan dengan melalui survei atau pembagian kuesioner kepada pihak pengambil keputusan dan stakeholders terkait. 


\section{c. Penentuan Target dan Inisiatif Strategis}

Tahap ini bertujuan untuk penentuan target dan inisiatif strategis berdasarkan pengukuran yang telah dirancang dan dikonfirmasikan kepada pihak Fakultas dan Unversitas.

d. Perancangan scorecard

Tahap ini perumusan sasaran strategis dan penentuan indikator hasil serta pembobotan akan direkapitulasi dalam sebuah bagan pengukuran yang dapat menampilkan keseluruhan aspek-aspek yang diukur dalam penelitian. Dalam hasil analisis, turut diselipkan target, hasil realisasi dan tingkat pencapaian dari realisasi indikator-indikator hasil yang telah ditentukan sebelumnya.

e. Implementasi balanced scorecard

Implementasi pendekatan ini adalah hasil pengukuran dari kinerja akademik di Fakultas Teknik Universitas Krisnadwipayana (Unkris). Dalam implementasi, nantinya menampilkan skor penilaian dan persen pencapaian target berdasarkan indikatorindikator kinerja.

\section{Analisa hasil dan pembahasan \\ Penterjemahan visi, misi dan tujuan ke dalam sasaran strategis}

Berdasarkan visi dan misi dari Fakultas Teknik Universitas Krisnadwipayana, 23 sasaran strategis yang ingin dicapai oleh Fakultas Teknik Unkris dirumuskan. Perumusan sasaran strategis ini berdasarkan hasil kuesioner yang disebarkan kepada 20 responden yang terdiri atas: 5 orang dari pejabat struktural, 10 orang tenaga pengajar tetap, dan 5 orang staf yang ada di lingkungan Fakultas Teknik Unkris. Hasil skor penilaian responden berdasarkan skala likert pada Tabel 1.

Berdasarkan perhitungan nilai rata-rata skor dari dua puluh tiga sasaran strategis tersebut semuanya di atas 2.5 . Hal ini berarti penilaian responden terhadap sasaran-sasaran strategis tersebut semuanya telah memenuhi kriteria penilaian. Pada Tabel 1 terlihat bahwa dari sisi keuangan, hampir semua responden (94\%) setuju dan sangat setuju untuk meningkatkan penerimaan fakultas. $44 \%$ responden setuju dan $31 \%$ sangat setuju untuk meningkatkan realisasi penggunaan anggaran. Selain itu, sebagian besar responden $(62 \%)$ juga setuju dan sangat setuju untuk meningkatkan alokasi dana operasional untuk kegiatan seperti pendidikan, penelitian dan pengabdian kepada masyarakat. Serta untuk meningkatkan penerimaan, sebagian besar responden juga setuju dan sangat setuju untuk meningkatkan jumlah penerimaan mahasiswa dan memperluas pasar dengan menjaring mahasiswa dari luar daerah.

Responden juga melihat pentingnya peningkatan kualitas lulusan dalam sasaran strategis yang perlu ditetapkan. Tabel 3 menunjukkan 56\% responden setuju dan $38 \%$ sangat setuju dengan perlu adanya usaha untuk meningkatkan IPK lulusan agar mampu bersaing dengan lulusan dari perguruan tinggi lainnya. Setengah dari responden (50\%) juga setuju untuk menghasilkan lulusan yang cepat terserap oleh pasar kerja dengan mempercepat waktu tunggu lulusan. Hampir semua responden (94\%) setuju dan sangat setuju untuk dapat menghasilkan lulusan dengan kemampuan bahasa Inggris yang baik agar dapat berkiprah di industri global. Selain itu, sebagian besar responden (88\%) juga setuju dan sangat setuju bahwa pendidikan di Fakultas Teknik diharapkan dapat menghasilkan lulusan yang menjadi wirausaha dalam bidangnya.

Peningkatan kualitas lulusan ini perlu didukung oleh mutu proses pendidikan di Fakultas Teknik Unkris. $63 \%$ responden sangat setuju untuk meningkatkan status akreditasi program studi. $94 \%$ responden setuju dan sangat setuju untuk meningkatkan fasilitas laboratorium, ruang kelas dan bahan pustaka. Semua responden juga setuju dan sangat setuju untuk meningkatkan jumlah kegiatan penelitian dan pengabdian masyarakat. 56\% responden setuju dan 38\% sangat setuju diperlukan peningkatan publikasi ilmiah dan peningkatan jumlah SAP dan modul mata kuliah. $69 \%$ responden juga setuju untuk meningkatkan jumlah kerjasama dengan instutusi di dalam dan luar negeri. Semua responden (100\%) juga setuju dan sangat setuju untuk meningkatkan jumlah dosen berpendidikan S2 dan S3. Selain itu, 94\% responden juga setuju dan sangat setuju untuk meningkatkan penggunaan teknologi informasi dalam PBM untuk meningkatkan kualitas proses pendidikan di Fakultas Teknik Unkris. 
Tabel 1. Hasil skor penilaian responden

\begin{tabular}{|c|c|c|c|c|c|c|c|}
\hline \multirow[b]{2}{*}{ No. } & \multirow[b]{2}{*}{ Sasaran Strategis } & \multirow[b]{2}{*}{$\begin{array}{l}\text { Rata- } \\
\text { rata } \\
\text { skor }\end{array}$} & \multicolumn{5}{|c|}{ Persentase \% } \\
\hline & & & $\begin{array}{l}\text { Mutlak } \\
\text { tidak } \\
\text { setuju }\end{array}$ & $\begin{array}{l}\text { Tidak } \\
\text { Setuju }\end{array}$ & Netral & Setuju & $\begin{array}{l}\text { Mutlak } \\
\text { Sangat } \\
\text { Setuju }\end{array}$ \\
\hline 1. & $\begin{array}{l}\text { Meningkatnya } \\
\text { Pemasukan Fakultas }\end{array}$ & 4,42 & $0 \%$ & $0 \%$ & $25 \%$ & $8 \%$ & $67 \%$ \\
\hline 2. & $\begin{array}{l}\text { Meningkatnya realisasi } \\
\text { penggunaan anggaran }\end{array}$ & 4,33 & $0 \%$ & $0 \%$ & $25 \%$ & $17 \%$ & $58 \%$ \\
\hline 3. & $\begin{array}{l}\text { Meningkatnya alokasi } \\
\text { dana operasional untuk } \\
\text { kegiatan Tridarma } \\
\text { Perguruan Tinggi }\end{array}$ & 4,75 & $0 \%$ & $0 \%$ & $8 \%$ & $8 \%$ & $83 \%$ \\
\hline 4. & $\begin{array}{l}\text { Meningkatnya jumlah } \\
\text { intake mahasiswa }\end{array}$ & 4,67 & $0 \%$ & $0 \%$ & $8 \%$ & $17 \%$ & $75 \%$ \\
\hline 5. & $\begin{array}{l}\text { Meningkatnya jumlah } \\
\text { mahasiswa dari luar } \\
\text { daerah }\end{array}$ & 4,67 & $0 \%$ & $0 \%$ & $8 \%$ & $17 \%$ & $75 \%$ \\
\hline 6. & $\begin{array}{l}\text { Meningkatnya Indeks } \\
\text { Prestasi Kumulatif (IPK) } \\
\text { lulusan }\end{array}$ & 4,42 & $0 \%$ & $8 \%$ & $17 \%$ & $0 \%$ & $75 \%$ \\
\hline 7. & $\begin{array}{l}\text { Mempersingkat waktu } \\
\text { tunggu lulusan untuk } \\
\text { mendapat pekerjaan } \\
\text { pertama }<3 \text { bulan }\end{array}$ & 4,50 & $0 \%$ & $0 \%$ & $8 \%$ & $33 \%$ & $58 \%$ \\
\hline 8. & $\begin{array}{l}\text { Meningkatnya } \\
\text { Kemampuan Berbahasa } \\
\text { Inggris }\end{array}$ & 4,42 & $0 \%$ & $0 \%$ & $17 \%$ & $25 \%$ & $58 \%$ \\
\hline 9. & $\begin{array}{l}\text { Meningkatnya jumlah } \\
\text { lulusan yang menjadi } \\
\text { entrepreneur/wirausaha }\end{array}$ & 4,25 & $0 \%$ & $0 \%$ & $25 \%$ & $25 \%$ & $50 \%$ \\
\hline 10. & $\begin{array}{l}\text { Meningkatnya status } \\
\text { akreditasi setiap program } \\
\text { studi }\end{array}$ & 4,33 & $0 \%$ & $8 \%$ & $17 \%$ & $8 \%$ & $67 \%$ \\
\hline 11. & $\begin{array}{lr}\text { Meningkatnya fasilitas } \\
\text { laboratorium ruang kelas } \\
\text { dan } \\
\text { referensi/pustaka } \\
\text { mutakhir }\end{array}$ & 4,58 & $0 \%$ & $0 \%$ & $8 \%$ & $25 \%$ & $67 \%$ \\
\hline 12. & $\begin{array}{l}\text { Meningkatnya jumlah } \\
\text { penelitian dan } \\
\text { pengabdian masyarakat }\end{array}$ & 4,50 & $0 \%$ & $0 \%$ & $17 \%$ & $17 \%$ & $67 \%$ \\
\hline 13. & $\begin{array}{l}\text { Meningkatnya jumlah } \\
\text { publikasi ilmiah nasional }\end{array}$ & 4,50 & $0 \%$ & $0 \%$ & $17 \%$ & $17 \%$ & $67 \%$ \\
\hline 14. & $\begin{array}{lr}\text { Meningkatnya } & \text { jumlah } \\
\text { publikasi } & \text { ilmiah } \\
\text { internasional } & \\
\end{array}$ & 4,33 & $0 \%$ & $0 \%$ & $17 \%$ & $33 \%$ & $50 \%$ \\
\hline 15. & $\begin{array}{l}\text { Melengkapi RPS, Silabus } \\
\text { dan modul kuliah }\end{array}$ & 4,08 & $0 \%$ & $0 \%$ & $17 \%$ & $8 \%$ & $50 \%$ \\
\hline
\end{tabular}




\begin{tabular}{|c|c|c|c|c|c|c|c|}
\hline \multirow[b]{2}{*}{ No. } & \multirow[b]{2}{*}{ Sasaran Strategis } & \multirow[b]{2}{*}{$\begin{array}{l}\text { Rata- } \\
\text { rata } \\
\text { skor }\end{array}$} & \multicolumn{5}{|c|}{ Persentase \% } \\
\hline & & & $\begin{array}{l}\text { Mutlak } \\
\text { tidak } \\
\text { setuju }\end{array}$ & $\begin{array}{l}\text { Tidak } \\
\text { Setuju }\end{array}$ & Netral & Setuju & $\begin{array}{l}\text { Mutlak } \\
\text { Sangat } \\
\text { Setuju }\end{array}$ \\
\hline 16. & $\begin{array}{l}\text { Meningkatnya kerjasama } \\
\text { dalam negeri dan luar } \\
\text { negeri }\end{array}$ & 4,50 & $0 \%$ & $0 \%$ & $17 \%$ & $8 \%$ & $58 \%$ \\
\hline 17. & $\begin{array}{l}\text { Meningkatnya jumlah } \\
\text { dosen berpendidikan } \mathrm{S} 2 \\
\text { dan } \mathrm{S} 3\end{array}$ & 4,42 & $0 \%$ & $0 \%$ & $25 \%$ & $8 \%$ & $67 \%$ \\
\hline 18. & $\begin{array}{l}\text { Meningkatnya jumlah } \\
\text { dosen yang studi lanjut }\end{array}$ & 4,33 & $0 \%$ & $0 \%$ & $25 \%$ & $17 \%$ & $58 \%$ \\
\hline 19. & $\begin{array}{ll}\text { Terpenuhinya } & \text { rasio } \\
\text { kecukupan dosen } & \end{array}$ & 4,75 & $0 \%$ & $0 \%$ & $8 \%$ & $8 \%$ & $83 \%$ \\
\hline 20. & $\begin{array}{lr}\text { Meningkatnya } & \text { dosen } \\
\text { yang } & \text { mengikuti } \\
\text { sertifikasi dosen dan } \\
\text { kompetensi }\end{array}$ & 4,67 & $0 \%$ & $0 \%$ & $8 \%$ & $17 \%$ & $75 \%$ \\
\hline 21. & $\begin{array}{l}\text { Meningkatnya jumlah } \\
\text { dosen yang menjadi } \\
\text { anggota } \\
\text { organisasi/asosiasi } \\
\text { profesi dan atau } \\
\text { keilmuan dalam negeri } \\
\text { atauluar negeri }\end{array}$ & 4,67 & $0 \%$ & $0 \%$ & $8 \%$ & $17 \%$ & $75 \%$ \\
\hline 22. & $\begin{array}{l}\text { Meningkatnya jumlah } \\
\text { tenaga kependidikan } \\
\text { yang mengikuti pelatihan } \\
\text { dan pendidikan sesuai } \\
\text { dengan bidang kerjanya }\end{array}$ & 4,42 & $0 \%$ & $8 \%$ & $17 \%$ & $0 \%$ & $75 \%$ \\
\hline 23. & $\begin{array}{l}\text { Meningkatnya } \\
\text { penggunaan teknologi } \\
\text { informasi dalam Proses } \\
\text { Belajar Mengajar }\end{array}$ & 4,50 & $0 \%$ & $0 \%$ & $8 \%$ & $33 \%$ & $58 \%$ \\
\hline
\end{tabular}

\section{Perancangan peta strategis}

Dua puluh tigas strategis di atas dijabarkan dalam suatu strategic map dengan mengelompokkannya ke dalam 4 (empat) perspektif, yaitu: perspektif keuangan, perspektif pelanggan, perspektif bisnis internal dan perspektif pertumbuhan dan pembelajaran seperti yang terlihat pada Gambar 1. Hubungan antara masing-masing sasaran strategis digambarkan melalui garis panah. Sasaran strategis yang ingin dicapai dalam ranah perspektif pertumbuhan dan pembelajaran, proses bisnis internal, dan perspektif pelanggan di atas adalah untuk mencapai sasaran akhir yaitu pada perspektif keuangan. 


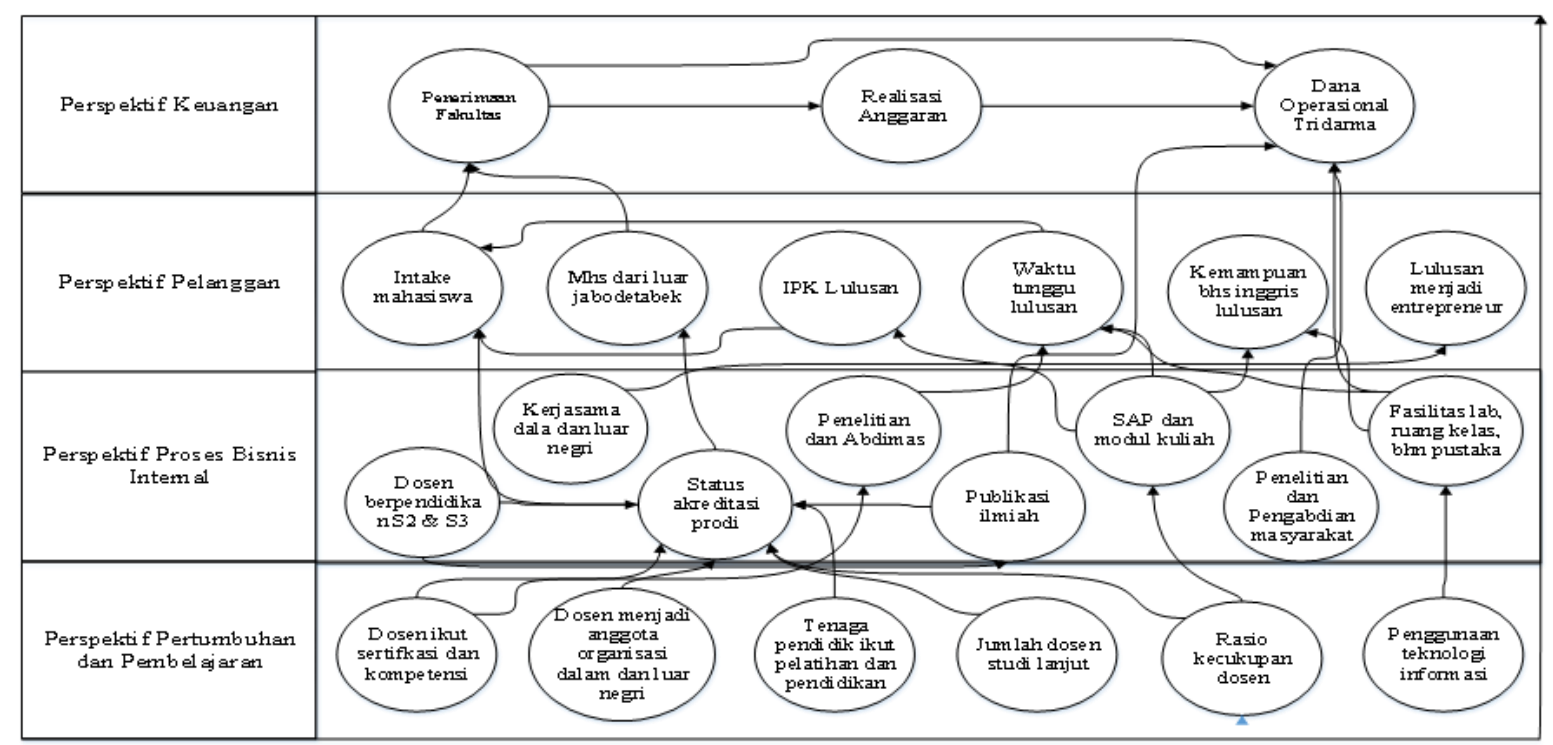

Gambar 1. Strategic map

\section{Penentuan indikator kinerja utama}

Indikator kinerja Key Performance Index (KPI) terdiri atas indikator hasil (lag indicator) dan indikator pemicu kinerja (lead indicator). Indikator kinerja utama adalah ukuran kinerja yang jelas terkait dengan sasaran strategis yang bisa mendorong sebuah organisasi untuk menterjemahkan sasaran-sasaran strategis menjadi terminologi yang bisa dikuantifikasi. Yang termasuk indikator pemicu kinerja (lead indicator) adalah indikator untuk persepektif pertumbuhan dan pembelajaran, proses bisnis internal dan pelanggan. Indikator hasil (lag indicator) adalah indikator untuk perspektif keuangan. Untuk kesembilan belas sasaran strategis di atas, perumusan indikator kinerja dapat dilihat pada Tabel 2.

\section{Penentuan prioritas strategis \\ Struktur hirarki}

Penentuan prioritas dari kesembilan belas sasaran strategis dilakukan dengan metode Analytical Hirarchy Process (AHP). Susunan hirarki dari penilaian kinerja Fakultas TeknikUnkris pada Gambar 4. Level pertama hirarki menunjukkan sasaran atau tujuan yang ingin dicapai, yaitu pengukuran kinerja di Fakultas Teknik Unkris. Pada level ke-2, adalah kriteria, dimana pengukuran kinerja berdasarkan pendekatan balanced scorecard yang menilai kinerja dari 4 perspektif, yaitu: keuangan, pelanggan, proses bisnis internal dan pertumbuhan dan pembelajaran. Level berikutnya dalam struktur hirarki adalah sub-sub kriteria untuk setiap perspektif.

Tabel 2. Indikator kinerja utama (key performance indicator)

\begin{tabular}{|c|c|c|}
\hline No & Sasaran- Sasaran Strategis & KPI \\
\hline 1 & Meningkatnya Pemasukan Fakultas & $\begin{array}{l}\text { Persentase kenaikan pemasukan fakultas } \\
\text { per tahun }\end{array}$ \\
\hline 2 & $\begin{array}{l}\text { Meningkatnya realisasi penggunaan } \\
\text { anggaran }\end{array}$ & Persentase realisasi anggaran per tahun \\
\hline 3 & $\begin{array}{l}\text { Meningkatnya alokasi dana operasional } \\
\text { untuk kegiatan Tridarma Perguruan } \\
\text { Tinggi }\end{array}$ & $\begin{array}{l}\text { Jumlah dana operasional untuk } \\
\text { pendidikan, penelitian dan pengabdian } \\
\text { masyarakat per mahasiswa }\end{array}$ \\
\hline 4 & $\begin{array}{l}\text { Meningkatnya jumlah intake } \\
\text { mahasiswa }\end{array}$ & $\begin{array}{l}\text { Persentase pertumbuhan jumlah } \\
\text { mahasiswa per tahun }\end{array}$ \\
\hline 5 & $\begin{array}{l}\text { Meningkatnya jumlah mahasiswa dari } \\
\text { luar daerah }\end{array}$ & $\begin{array}{l}\text { Persentase jumlah mahasiswa luar daerah } \\
\text { per tahun }\end{array}$ \\
\hline
\end{tabular}




\begin{tabular}{|c|c|c|}
\hline No & Sasaran- Sasaran Strategis & KPI \\
\hline 6 & $\begin{array}{l}\text { Meningkatnya Indeks } \quad \text { Prestasi } \\
\text { Kumulatif (IPK) lulusan }\end{array}$ & Rata-rata IPK lulusan setiap tahun \\
\hline 7 & $\begin{array}{l}\text { Mempersingkat waktu tunggu lulusan } \\
\text { hingga mendapat pekerjaan pertama (< } \\
3 \text { bulan) }\end{array}$ & Rata-rata waktu tunggu lulusan $<3$ bulan \\
\hline 8 & $\begin{array}{l}\text { Meningkatnya Kemampuan Berbahasa } \\
\text { Inggris }\end{array}$ & $\begin{array}{l}\text { Rata-rata skor TOEFL lulusan per tahun > } \\
400\end{array}$ \\
\hline 9 & $\begin{array}{l}\text { Meningkatnya jumlah lulusan yang } \\
\text { menjadi wirausaha/ entrepreneur }\end{array}$ & $\begin{array}{l}\text { \% lulusan yang menjadi wirausaha per } \\
\text { tahun }\end{array}$ \\
\hline 10 & $\begin{array}{l}\text { Meningkatnya status akreditasi setiap } \\
\text { program-program studi }\end{array}$ & Status Akreditasi setiap prodi minimal (B) \\
\hline 11 & $\begin{array}{l}\text { Meningkatnya fasilitas laboratorium } \\
\text { ruang kelas dan daftar referensi/pustaka } \\
\text { yang mutakhir }\end{array}$ & $\begin{array}{l}\text { Persentase kelengkapan } \\
\text { laboratorium, rasio jumlah kelas per } \\
\text { jumlah mahasiswa, Jumlah buku dan } \\
\text { jurnal yang tersedia di perpustakaan }\end{array}$ \\
\hline 12 & $\begin{array}{l}\text { Meningkatnya jumlah penelitian dan } \\
\text { pengabdian kepada masyarakat }\end{array}$ & $\begin{array}{l}\text { Rata-rata kegiatan penelitian dan } \\
\text { pengabdian kepada masyarakat per dosen } \\
\text { setiap tahun }\end{array}$ \\
\hline 13 & $\begin{array}{l}\text { Meningkatnya jumlah publikasi ilmiah } \\
\text { nasional }\end{array}$ & $\begin{array}{l}\text { Rata-rata jumlah publikasi ilmiah di } \\
\text { prosiding seminar dan jurnal-jurnal } \\
\text { nasional setiap dosen per tahun }\end{array}$ \\
\hline 14 & $\begin{array}{l}\text { Meningkatnya jumlah publikasi ilmiah } \\
\text { internasional }\end{array}$ & $\begin{array}{l}\text { Rata-rata jumlah publikasi ilmiah di } \\
\text { prosiding seminar dan jurnal-jurnal } \\
\text { internasional setiap dosen per tahun }\end{array}$ \\
\hline 15 & $\begin{array}{l}\text { Melengkapi RPS, Silabus dan modul } \\
\text { kuliah }\end{array}$ & $\begin{array}{l}\text { Persentase jumlah RPS, Silabus dan } \\
\text { modul kuliah yang tersedia dari seluruh } \\
\text { mata kuliah }\end{array}$ \\
\hline 16 & $\begin{array}{l}\text { Meningkatnya kerjasama baik dalam } \\
\text { negeri maupun luar negeri }\end{array}$ & $\begin{array}{l}\text { Jumlah kerjasama baik dalam negeri } \\
\text { maupun luar negeri per tahun }\end{array}$ \\
\hline 17 & $\begin{array}{l}\text { Meningkatnya jumlah dosen } \\
\text { berpendidikan S2 dan S3 }\end{array}$ & $\begin{array}{l}\text { Persentase dosen } \\
\text { pendidikan S2 dan S3 }\end{array}$ \\
\hline 18 & $\begin{array}{l}\text { Meningkatnya jumlah dari dosen yang } \\
\text { studi lanjut }\end{array}$ & $\begin{array}{l}\text { Jumlah dari dosen yang studi lanjut per } \\
\text { tahun }\end{array}$ \\
\hline 19 & Terpenuhinya rasio kecukupan dosen & $\begin{array}{l}\text { Rasio jumlah dosen dan jumlah } \\
\text { mahasiswa }\end{array}$ \\
\hline 20 & $\begin{array}{l}\text { Meningkatnya dosen yang mengikuti } \\
\text { sertifikasi dosen dan kompetensi }\end{array}$ & $\begin{array}{l}\text { Jumlah dari dosen yang mengikuti } \\
\text { sertifikasi dosen }\end{array}$ \\
\hline 21 & $\begin{array}{l}\text { Meningkatnya jumlah dosen yang } \\
\text { berpartisipasi menjadi anggota } \\
\text { organisasi/asosiasi profesi dan atau } \\
\text { keilmuan baik di dalam negeri atau luar } \\
\text { negeri }\end{array}$ & $\begin{array}{l}\text { Jumlah dosen yang berpartisipasi menjadi } \\
\text { anggota profesi baik di dalam negeri atau } \\
\text { luar negeri }\end{array}$ \\
\hline
\end{tabular}




\begin{tabular}{|l|l|l|}
\hline No & Sasaran- Sasaran Strategis & KPI \\
\hline 22 & $\begin{array}{l}\text { Meningkatnya jumlah tenaga pendidik } \\
\text { yang mengikuti pendidikan dan } \\
\text { pelatihan sesuai dengan bidang } \\
\text { kerjanya }\end{array}$ & $\begin{array}{l}\text { Jumlah tenaga pendidik yang mengikuti } \\
\text { pendidikan dan pelatihan sesuai dengan } \\
\text { bidang kerjanya }\end{array}$ \\
\hline 23 & $\begin{array}{l}\text { Meningkatnya penggunaan teknologi } \\
\text { informasi dalam Proses Belajar } \\
\text { Mengajar }\end{array}$ & $\begin{array}{l}\text { Ketersediaan sistem informasi dan } \\
\text { jaringan yang memadai untuk akses } \\
\text { secara online. }\end{array}$ \\
\hline
\end{tabular}

\section{Pengolahan dengan menggunakan metode analytical hierarchy process (AHP)}

Proses pengolahan data menggunakan metode AHP ini dimulai dengan melihat hasil kuisioner yang telah diisi oleh responden yang berasal dari pimpinan di Universitas Krisnadwipa. Hasil kuisioner yang berupa tabel perbandingan berpasangan akan diolah menggunakan AHP sehingga nantinya dapat diketahui bobot prioritas dari masing-masing kriteria dan sub kriteria. Pengolahan data menggunakan metode AHP dimulai dari mentransformasikan hasil jawaban responden ke skala saaty, mencari nilai matriks, menghitung nilai consistency masing-masing kriteria, baik consistency index maupun consistency ratio, dan terakhir adalah normalisasi bobot.

Sehingga dapat diketahui nantinya mana kriteria dan sub kriteria terpilih dengan bobot paling tinggi. Berikut merupakan langkah-langkah pengolahan data dengan menggunakan metode AHP:

1. Hasil jawaban responden untuk setiap kriteria dan sub kriteria

Hasil jawaban responden pada kuisioner yang telah disebar harus ditransformasikan dahulu ke dalam bentuk skala saaty, dan dinputkan kedalam tabel perhitungan. Sebelumnya berikut merupakan salah satu contoh kuisioner perbandingan berpasangan untuk kriteria faktor.

Tabel 3. Contoh kuisioner perbandingan berpasangan untuk kriteria faktor

\begin{tabular}{|c|c|c|c|c|c|c|c|c|c|c|}
\hline Kriteria & $\begin{array}{l}\text { A. } \operatorname{lmp} \\
(9,9,9)\end{array}$ & $\begin{array}{l}\text { S. Imp } \\
(6,7,8)\end{array}$ & \begin{tabular}{|l|} 
F. $\operatorname{lmp}$ \\
$(4,5,6)$
\end{tabular} & $\begin{array}{l}\text { W. Imp } \\
(2,3,4)\end{array}$ & \begin{tabular}{|c|} 
Eq. Imp \\
$(1,1,1)$
\end{tabular} & \begin{tabular}{|l|} 
W. Imp \\
$(2,3,4)$
\end{tabular} & $\begin{array}{l}\text { F. Imp } \\
(4,5,6)\end{array}$ & $\begin{array}{l}\text { S. Imp } \\
(6,7,8)\end{array}$ & $\begin{array}{l}\text { A. Imp } \\
(9,9,9)\end{array}$ & Kriteria \\
\hline Keuangan & & & & & & 3 & & & & Pelanggan \\
\hline Keuangan & & & & & 1 & & & & & Proses Bisnis Internal \\
\hline Keuangan & & & & 3 & & & & & & $\begin{array}{c}\text { Pertumbuhan dan } \\
\text { Pembelajaran }\end{array}$ \\
\hline Pelanggan & & & & 3 & & & & & & Proses Bisnis Internal \\
\hline Pelanggan & & & 5 & & & & & & & $\begin{array}{c}\text { Pertumbuhan dan } \\
\text { Pembelajaran }\end{array}$ \\
\hline $\begin{array}{l}\text { Proses Bisnis } \\
\text { Internal }\end{array}$ & & & 5 & & & & & & & $\begin{array}{c}\text { Pertumbuhan dan } \\
\text { Pembelajaran }\end{array}$ \\
\hline
\end{tabular}

Penilaian untuk masing-masing pertanyaan dilakukan dengan cara memberi check $(\sqrt{ })$ pada masing-masing kolom yang telah disusun berdasarkan kriteria dan subkriteria yang telah ditentukan. Penilaian yang dilakukan berdasarkan atas pengalaman, infrastruktur, dan persepsi terhadap masing-masing perspektif yang dianggap sesuai dengan situasi dan kondisi. Penilaian dari masing-masing responden akan menghasilkan pandangan yang berbeda. Berikut merupakan akumulasi hasil penilaian perbandingan berpasangan untuk masing-masing perspektif.

Tabel 4. Hasil Penilaian untuk setiap perspektif

\begin{tabular}{|c|c|c|c|c|}
\hline Kriteria & Keuangan & Pelanggan & $\begin{array}{c}\text { Proses Bisnis } \\
\text { Internal }\end{array}$ & $\begin{array}{c}\text { Pertumbuhan dan } \\
\text { Pembelajaran }\end{array}$ \\
\hline Keuangan & 1.00 & 0.33 & 1.00 & 3.00 \\
\hline Pelanggan & 3.00 & 1.00 & 3.00 & 5.00 \\
\hline Proses Bisnis Internal & 1.00 & 0.33 & 1.00 & 5.00 \\
\hline $\begin{array}{c}\text { Pertumbuhan dan } \\
\text { Pembelajaran }\end{array}$ & 0.33 & 0.20 & 0.20 & 1.00 \\
\hline
\end{tabular}

Berdasarkan tabel diatas dapat dilihat bahwa penilain responden terhadap masingmasing perspektif beragam. Tapi masih dalam jangkaun antara skala 1 (sama penting) 
hingga 5 (cukup penting). Contohnya pada kriteria pelanggan dan keuangan. Dimana hasil penilaian perbandingan berpasangan antara kriteria ini adalah 3 . Hal ini memiliki arti bahwa kriteria pelanggan sedikit lebih penting dari pada kriteria keuangan. Sehingga jika dilihat dari kebalikannya bobot kriteria keuangan yang diabndingkan dengan kriteria pelanggan akan bernilai 0.33 yang berarti kriteria keuangan tidak lebih penting dibandingkan dengan kriteria pelanggan.

2. Perhitungan nilai matriks untuk masing-masing kriteria

Sebelum masuk ke perhitungan Consistency index dan Consistency ratio, langkah selanjutnya setelah hasil penilaian perbandingan berpasangan di transformasikan ke skala saaty dengan menghitung nilai eigen masing-masing kriteria. Nilai eigen didapatkan dihitung dengan menjumlahkan masing-masing nilai perspektif baik secara vertical. Kemudian membagi nilai masing-masing perspektif dengan total nilai untuk masingmasing perspektif. Setelah itu baru dihitung jumlah dan rata-rata untuk setiap baris nya. total nilai setelah dirata-ratakan pasti 1 , jika hasil perhitungan total nilai lebih atau pun kurang dari 1 maka terdapat kesalahan dalam perhitungan. Berikut merupakan rincian perhitungan untuk faktor kriteria.

\section{Tabel 5. Perhitungan nilai matriks untuk faktor kriteria}

\begin{tabular}{|c|c|c|c|c|c|}
\hline \multicolumn{4}{|c|}{ Nilai Eigen } & Jumlah & Rata-rata \\
\hline 0.19 & 0.18 & 0.19 & 0.21 & 0.77 & 0.19 \\
\hline 0.56 & 0.54 & 0.58 & 0.36 & 2.03 & 0.51 \\
\hline 0.19 & 0.18 & 0.19 & 0.36 & 0.92 & 0.23 \\
\hline 0.06 & 0.11 & 0.04 & 0.07 & 0.28 & 0.07 \\
\hline & & & & Total & 1.00 \\
\hline
\end{tabular}

Berdasarkan hasil perhitungan diketahui nilai rata-rata eigen yang paling tinggi terdapat pada kriteria pelanggan dengan nilai 0.51. Sedangkan nilai total untuk kriteria faktor adalah 1, jadi bias dikatakan tidak ada kesalahan perhitungan untuk nilai eigen dari kriteria faktor tersebut.

3. Perhitungan consistency index dan consistency ratio

Langkah selanjutnya adalah mengitung nilai Consistency index dan Consisteny Ratio. Perhitungan ini dilakukan untuk melihat apakah data sudah konsitensi atau belum. Dimana data dinyatakan konsisten apabila hasil uji Consistency ratio (CR) memiliki rentang nilai $\leq 0,1$ apabila nilai $C R$ memiliki nilai yang $>0,1$ maka data penilaian perbandingan berpasangan dinyatakan tidak konsisten dan pengambilan data harus diulangi kembali hingga mendapatkan hasil yang konsisten. Sedangkan, jika nilai konsistensi bernilai kecil sama dari 0.1, maka perhitungan dinyatakan benar dan keputusan dapat dinyatakan sudah konsisten (Sonata, 2018). Berikut merupakan tabel perhitungan nilai Consistency index dan Consistency ratio untuk kriteria faktor.

\section{Tabel 6. Perhitungan Nilai Matriks untuk Faktor Kriteria}

\begin{tabular}{|c|c|c|c|c|c|}
\hline \multicolumn{4}{|c|}{ Nilai Eigen } & Jumlah & Rata-rata \\
\hline 0.19 & 0.18 & 0.19 & 0.21 & 0.77 & 0.19 \\
\hline 0.56 & 0.54 & 0.58 & 0.36 & 2.03 & 0.51 \\
\hline 0.19 & 0.18 & 0.19 & 0.36 & 0.92 & 0.23 \\
\hline 0.06 & 0.11 & 0.04 & 0.07 & 0.28 & 0.07 \\
\hline \multirow{4}{*}{} & Total & 1.00 \\
\cline { 4 - 5 } & $\begin{array}{c}\text { Lamda } \\
\text { Max }\end{array}$ & 4.15 \\
\cline { 4 - 5 } & CI & 0.05 \\
\cline { 4 - 5 } & RI & 0.90 \\
\cline { 4 - 5 } & CR & 0.05 \\
\cline { 3 - 5 }
\end{tabular}


faktor:

Berikut merupakan contoh perhitungan uji Consistency index (CI) untuk kriteria

$\mathrm{CI}=\frac{(\lambda \max -\mathrm{n})}{\mathrm{n}-1}$

$\mathrm{CI}=\frac{(4.15-4)}{4-1}$

$\mathrm{CI}=0,05$

Setelah didapatkan hasil dari Consistency index, langkah selanjutnya adalah menentukan Consistency ratio nya :

$\mathrm{CR}=\frac{\mathrm{CI}}{\mathrm{RI}}$
$\mathrm{CR}=\frac{0,05}{0.90}$
$\mathrm{CR}=0,05$

Berdasarkan perhitungan yang telah dilakukan didapatkan hasil bahwa nilai CR untuk kriteria faktor memiliki nilai yang $\leq 0,1$ yaitu nya 0.05 . Perhitungan yang sama juga dilakukan untuk masing-masing perspektif dan didapatkan hasil 0.05 untuk perspektif keuangan, 0.07 untuk perspektif pelanggan. Kemudian 0.08 untuk perspektif proses bisnis internal dan 0.06 untuk perspektif pertumbuhan dan pembelajaran. Sehingga dapat diambil kesimpulan bahwa hasil uji CR untuk masing-masing perspektif oleh responden sudah konsisten.

Penghitungan bobot setiap sasaran strategis

Penghitungan bobot untuk setiap sasaran strategis menggunakan kaedah matriks perbandingan berpasangan, dimana setiap kriteria dibandingkan dengan kriteria lainnya dan diberikan skor perbandingan antara 1 sampai 9. Nilai skor pada matriks perbandingan berpasangan didapatkan dari rata-rata skor yang diberikan oleh responden dengan metode Geometric Mean sebagai berikut :

$$
\begin{array}{ll}
\text { Zrata-rata }=(\mathrm{Z} 1 \times \mathrm{Z} 2 \times \mathrm{Z} 3 \times \ldots . . \times \mathrm{Zn}) 1 / \mathrm{n} \\
\text { dimana: } & \\
\begin{array}{ll}
\mathrm{Zrata}-\mathrm{rata} & =\text { nilai skor rata-rata seluruh responden } \\
\mathrm{Zi} & =\text { nilai skor setiap responden } \\
\mathrm{n} & =\text { jumlah responden }
\end{array}
\end{array}
$$

Hasil normalisasi dari matriks perbandingan berpasangan antar kriteria adalah seperti pada Tabel 5. Matriks di atas menunjukkan bahwa bobot prioritas untuk setiap perspektif hampir berimbang. Artinya semua perspektif memiliki prioritas yang hampir sama untuk dikerjakan dalam rangka peningkatan kinerja Fakultas Teknik Unkris.

Kriteria perpektif pelanggan merupakan kriteria yang menjadi prioritas tertinggi untuk dicapai dengan bobot 0.51 atau $51 \%$. diikuti oleh kriteria perspektif proses bisnis internal dengan bobot masing-masing 0.23 atau 23\%. Selanjutnya kriteria perspektif keuangan mempunyai bobot prioritas terkecil dengan bobot 0.19 atau $19 \%$ dan perspektif pertumbhan dan pembelajaran sebesar 0.07 atau 7\%. Nilai rasio konsistensi (CR) untuk faktor keriteria adalah 0.05 atau $5 \%$, yang berarti penilaian dapat diterima atau konsisten karena nilai CR kurang dari $10 \%$.

Matriks perbandingan berpasangan antar sub kriteria dilakukan dengan cara penghitungan yang sama. 


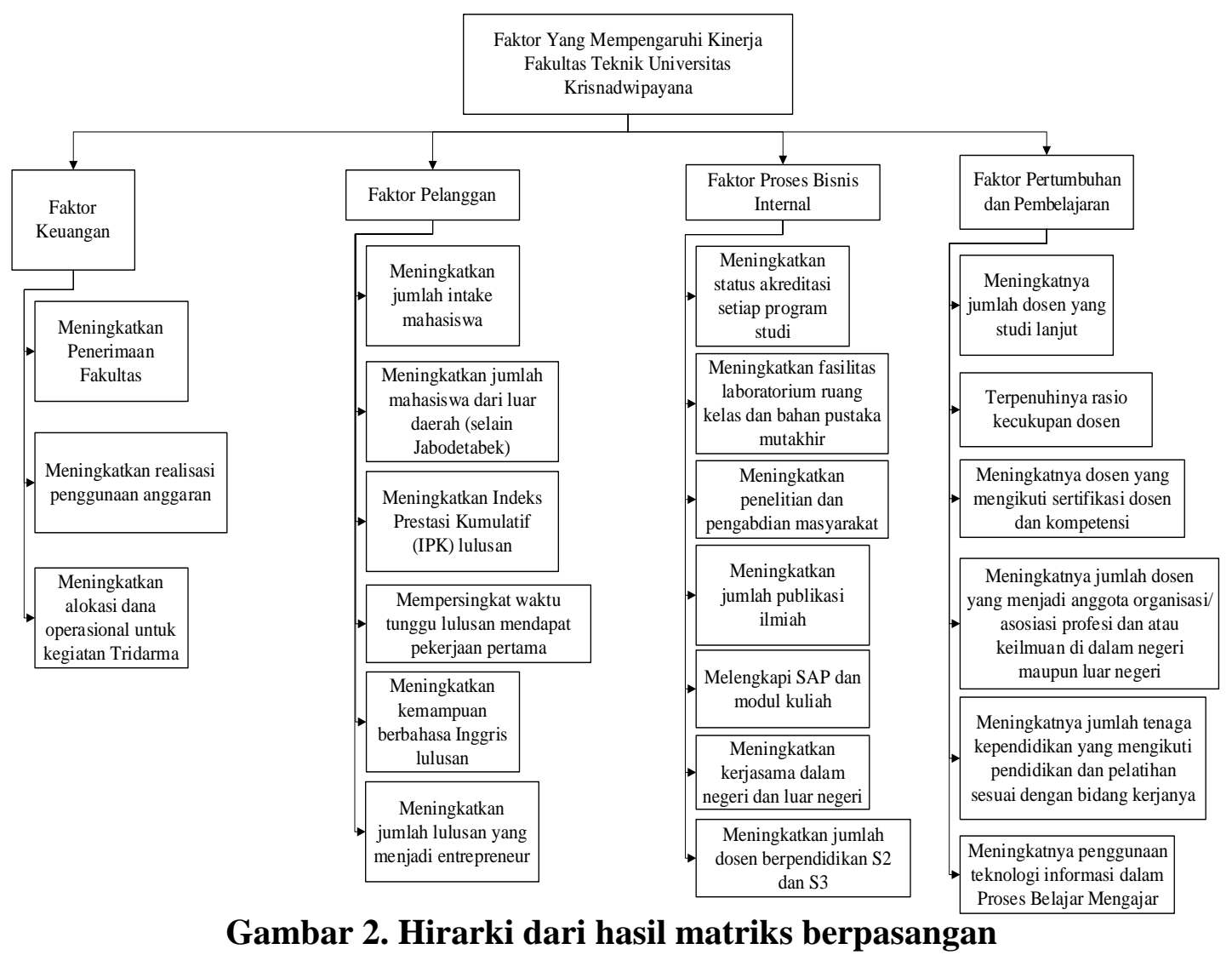

Hasil perbandingan berpasangan pada kriteria perspektif keuangan, sub kriteria dengan bobot paling tinggi adalah meningkatnya realisasi penggunaan anggaran sebesar 0.63 atau 63\%. Pada kriteria perspektif pelanggan, sub kriteria dengan bobot paling tinggi adalah meningkatnya jumlah mahasiswa dari luar daerah dengan bobot 0.30 atau $30 \%$. Sasaran strategis berikutnya yang menjadi prioritas pada perspektif proses bisnis internal adalah meningkatnya jumlah publikasi ilmiah nasional dengan bobot 0.18 atau $18 \%$, diikuti oleh meningkatnya jumlah dosen yang studi lanjut dengan bobot 0.29 atau $29 \%$ pada perspektif pertumbuhan dan pembelajaran.

\begin{tabular}{|c|c|c|c|c|}
\hline $\begin{array}{l}\text { Perspektif } \\
\text { (1) }\end{array}$ & $\begin{array}{l}\text { Bobot } \\
(2)\end{array}$ & Sub kriteria/ Sasaran Strategis (3) & $\begin{array}{c}\text { Bobot } \\
\text { sub } \\
\text { kriteria } \\
\text { (4) }\end{array}$ & $\begin{array}{c}\text { Bobot } \\
\text { Akhir } \\
\text { (2) } \times(4)\end{array}$ \\
\hline \multirow{3}{*}{ Keuangan } & \multirow{3}{*}{0.19} & Meningkatnya Pemasukan Fakultas & 0.26 & 0.05032 \\
\hline & & Meningkatnya realisasi penggunaan anggaran & 0.63 & 0.12234 \\
\hline & & $\begin{array}{c}\text { Meningkatnya alokasi dana operasional untuk kegiatan } \\
\text { Tridarma Perguruan Tinggi }\end{array}$ & 0.11 & 0.02051 \\
\hline \multirow{6}{*}{ Pelanggan } & \multirow{6}{*}{0.51} & Meningkatnya jumlah intake mahasiswa & 0.28 & 0.14362 \\
\hline & & Meningkatnya jumlah mahasiswa dari luar daerah & 0.30 & 0.15461 \\
\hline & & Meningkatnya Indeks Prestasi Kumulatif (IPK) lulusan & 0.23 & 0.11751 \\
\hline & & $\begin{array}{l}\text { Mempersingkat waktu tunggu masing-maisng lulusan } \\
\text { untuk mendapat pekerjaan pertama }(<3 \text { bulan })\end{array}$ & 0.09 & 0.04703 \\
\hline & & Meningkatnya Kemampuan Berbahasa Inggris & 0.04 & 0.02197 \\
\hline & & $\begin{array}{c}\text { Meningkatnya jumlah lulusan yang menjadi } \\
\text { entrepreneur/wirausaha }\end{array}$ & 0.05 & 0.02333 \\
\hline
\end{tabular}




\begin{tabular}{|c|c|c|c|c|}
\hline $\begin{array}{l}\text { Perspektif } \\
\text { (1) }\end{array}$ & $\begin{array}{l}\text { Bobot } \\
(2)\end{array}$ & Sub kriteria/ Sasaran Strategis (3) & $\begin{array}{c}\text { Bobot } \\
\text { sub } \\
\text { kriteria } \\
(4)\end{array}$ & $\begin{array}{l}\text { Bobot } \\
\text { Akhir } \\
(2) \times(4)\end{array}$ \\
\hline \multirow{8}{*}{$\begin{array}{l}\text { Proses Bisnis } \\
\text { Internal }\end{array}$} & \multirow{8}{*}{0.23} & Meningkatnya status akreditasi setiap program studi & 0.14 & 0.03244 \\
\hline & & $\begin{array}{l}\text { Meningkatnya fasilitas laboratorium ruang kelas dan } \\
\text { daftar referensi/pustaka yang mutakhir }\end{array}$ & 0.11 & 0.02412 \\
\hline & & $\begin{array}{l}\text { Meningkatnya jumlah penelitian dan pengabdian } \\
\text { masyarakat }\end{array}$ & 0.13 & 0.0299 \\
\hline & & Meningkatnya jumlah publikasi ilmiah nasional & 0.18 & 0.04125 \\
\hline & & Meningkatnya jumlah publikasi ilmiah internasional & 0.16 & 0.03717 \\
\hline & & Melengkapi RPS, Silabus dan modul kuliah & 0.09 & 0.02023 \\
\hline & & Meningkatnya kerjasama dalam negeri dan luar negeri & 0.07 & 0.01704 \\
\hline & & Meningkatnya jumlah dosen berpendidikan S2 dan S3 & 0.12 & 0.02672 \\
\hline \multirow{6}{*}{$\begin{array}{l}\text { Pertumbuhan } \\
\quad \text { dan } \\
\text { Pembelajaran }\end{array}$} & \multirow{6}{*}{0.07} & Meningkatnya jumlah dosen yang studi lanjut & 0.29 & 0.02016 \\
\hline & & Terpenuhinya rasio kecukupan dosen & 0.28 & 0.01931 \\
\hline & & $\begin{array}{c}\text { Meningkatnya dosen yang mengikuti sertifikasi dosen } \\
\text { dan kompetensi }\end{array}$ & 0.27 & 0.019 \\
\hline & & $\begin{array}{l}\text { Meningkatnya jumlah dosen yang berpartisipasi } \\
\text { menjadi anggota organisasi/asosiasi profesi dan atau } \\
\text { keilmuan baik di dalam negeri atau luar negeri }\end{array}$ & 0.07 & 0.00522 \\
\hline & & $\begin{array}{c}\text { Meningkatnya jumlah tenaga pendidik yang mengikuti } \\
\text { pelatihan dna pendidikan sesuai dengan bidang } \\
\text { kerjanya }\end{array}$ & 0.04 & 0.00276 \\
\hline & & $\begin{array}{c}\text { Meningkatnya penggunaan teknologi informasi dalam } \\
\text { Proses Belajar Mengajar }\end{array}$ & 0.05 & 0.00343 \\
\hline
\end{tabular}

Penghitungan bobot akhir untuk masing-masing sub kriteria adalah dengan mengalikan bobot masing-masing perspektif dengan masing-masing sub kriteria. Bobot akhir merepresentasikan tingkat kepentingan relatif setiap sasaran strategis dibandingkan dengan sasaran-sasaran strategis lainnya secara keseluruhan. Hasil perhitungan bobot akhir menunjukkan dari dua puluh tiga sasaran strategis tersebut, yang menjadi prioritas utama adalah meningkatnya realisasi penggunaan anggaran dengan bobot 0.1546 atau $15.46 \%$. Sedangkan nilai bobot akhir paling rendah adalah meningkatnya jumlah tenaga pendidik yang mengikuti pendidikan dan pelatihan yang sesuai dengan bidang kerjanya nya dengan bobot 0.002 atau $0.2 \%$ yang terdapat pada perskpektif pertumbuhan dan pembelajaran.

\section{Penentuan target dan inisiatif strategis}

Salah satu tahapan penting dalam merancang sistem pengukuran kinerja dengan menggunakan balanced scorecard adalah menentukan target untuk masing-masing sasaran strategis yang telah ditetapkan. Target merupakan tingkat kinerja yang ingin dicapai oleh suatu perusahaan atau institusi pada masa yang akan datang. Perumusan target-target kinerja di Fakultas Teknik Unkris berdasarkan pendapat dari pihak manajemen Fakultas Teknik Unkris dan berdasarkan kinerja masa lalu. Kinerja pada tahun sekarang menjadi acuan (baseline) untuk penetapan target pada masa yang akan datang. Penetapan target dari kinerja dibatasi untuk jangka waktu 3 (tiga) tahun ke depan dan dapat direvisi sesuai dengan perubahan yang mempengaruhinya. 
Inisiatif strategis adalah suatu pernyataan kualitatif berupa program-program strategis yang dilaksanakan biasanya dalam jangka waktu 3 (tiga) tahun mendatang untuk dapat mencapai sasaran-sasaran strategis. Inisiatif trategis yang dibuat harus tepat, realistis dan terkait dengan target, ukuran kinerja, dan sasaran strategis sehingga visi dan misi Fakultas dapat tercapai. Usulan target dan insiatif strategis untuk setiap sasaran strategis terdapat pada Tabel 7.

\section{SIMPULAN}

Dengan pendekatan Balanced scorecard, ditetapkan sasaran-sasaran strategis yang akan dicapai sesuai dengan visi, misi dan tujuan Fakultas Teknik Unkris. Berdasarkan hasil kuesioner, didapatkan 23 sasaran strategis, yang kemudian dirumuskan indikator kinerja utama (KPI) dari setiap sasaran strategis tersebut. Hasil perhitungan dengan metode Analytical Hirarchy Process (AHP) didapatkan sasaran-sasaran strategis yang menjadi prioritas dengan nilai bobot terbesar, yaitu meningkatkan penerimaan fakultas dengan bobot akhir $10 \%$. Prioritas berikutnya adalah meningkatkan jumlah dari dosen yang berpendidikan S2 dan S3 dengan bobot akhir 9\%, meningkatkan alokasi dana operasional untuk kegiatankegiatan Tridarma dengan bobot $8 \%$, meningkatkan jumlah dari penerimaan mahasiswa dengan bobot $7 \%$, serta meningkatkan jumlah realisasi anggaran, meningkatkan IPK dari lulusan dan meningkatkan dukungan teknologi dan informasi dalam PBM dengan bobot masing-masingnya 6\%. Penetapan target dan inisiatif stretegis menjadi langkah berikutnya, dimana target setiap sasaran strategis dirumuskan untuk 3 tahun mendatang berdasarkan kondisi pada saat sekarang. .

\section{DAFTAR PUSTAKA}

Abadi, S., Widyarto, S. 2018. The Designing Criteria and Sub-Criteria of University Balance Scorecard Using Analytical Hierarchy Process Method. International Journal of Engineering and Technology(UAE) DOI:10.14419/ijet.v7i2.29.14260.

Bakhtiar, I. 2005. Pengukuran Kinerja Perusahaan Dengan Pendekatan Metode Balanced scorecard Pada AJB Bumiputera 1912. Tesis Teknik Industri Fakultas Teknik Universitas Indonesia. Jakarta.

Harvey, Don \& Robert Bruce Bowin. 2006. Human Resousce Management : An Experiental Approach. New Jersey : Prentice Hall. Kaplan, Robert S, Norton, David P (2000), Balanced scorecard: Menerapkan Strategi Menjadi Aksi. Jakarta: Penerbit Erlangga.

Mulyadi.2005. Sistem Manajemen Strategik Berbasis Balanced scorecard. Yogyakarta: UPP AMP YKPN.

Palcic \& Lalic, 2009. Analytical Hierarchy Process As A Tool For Selecting And Evaluating Projects. International Journal Simulation Model Vol 8 No(1), 16-26.

Singgih, dkk. 2001. Pengukuran Dan Analisa Kinerja di PT "X" Dengan Metode Balanced scorecard. http://puslit.petra.ac.id/journals/industrial ).[27 Februari 2016].

Saaty, Thomas-L. 1993. Analitik Pengambilan Keputuan Bagi para pemimpin, proses Hirarki untuk Pengambilan Keputusan dalam situasi Kompleks, seri Manajemen No. 134. Jakarta : Pustaka Binaman pressindo.

Zagloel, T.Y.M. dan Nurcahyo, R. 2013. Total Quality Manajemen: Manajemen Kualitas Total dalam Perspektif Teknik Industri. PT. Indeks. Jakarta. Hal 82-83. 